Systematic Botany (2017), 42(4): pp. 830-834

(c) Copyright 2017 by the American Society of Plant Taxonomists

DOI $10.1600 / 036364417$ X696573

Date of publication December 18, 2017

\title{
A New Species of Croton section Lamprocroton (Euphorbiaceae) from Southern Brazil
}

\author{
Amanda da Paixão Noronha Pereira, ${ }^{1,4}$ Ricarda Riina, ${ }^{2}$ and Maria Beatriz Rossi Caruzo ${ }^{1,3}$ \\ ${ }^{1}$ Universidade Federal de São Paulo, Instituto de Ciências Ambientais, Químicas e Farmacêuticas, Departamento de Ecologia e \\ Biologia Evolutiva, Rua Prof. Artur Riedel, 275, Jd. Eldorado, 09972-270, Diadema, SP, Brazil \\ ${ }^{2}$ Real Jardín Botánico, RJB-CSIC, Plaza de Murillo 2, 28014 Madrid, Spain \\ ${ }^{3}$ Instituto de Botânica de São Paulo, Secretaria do Meio Ambiente, Cx. Postal 3005, 01061-970, São Paulo, SP, Brazil \\ ${ }^{4}$ Author for correspondence: (amanda.pnoronhap@gmail.com)
}

\section{Communicating Editor: Neil Snow}

\begin{abstract}
Croton longicarpus (Euphorbiaceae), a new species from southern Brazil, is here described and illustrated. The new species occurs in open vegetation and at the edges of Araucaria forest. The analysis of herbarium collections and observations from populations in the field indicate that the species has characters in common with members of Croton section Lamprocroton. The new species differs from other species in this section by its unusually elongated ovary and fruit, the narrowly spatulate sepals of the pistillate flowers, and long inflorescences.
\end{abstract}

Keywords-Crotoneae, diversity, Neotropics, taxonomy.

Croton $\mathrm{L}$. has about 1,200 species distributed in tropical and subtropical regions worldwide (Govaerts et al. 2000; Berry et al. 2005). Approximately two-thirds of the species are distributed in the New World (Van Ee et al. 2011) and 316 occur in Brazil (BFG 2015). Species in this genus usually can be recognized by a suite of characters, including an indumentum of stellate or lepidote trichomes, clear or colored latex, leaves that become orange when senescent, anthers inflexed in bud, and thyrsoid inflorescences (Webster 1967; Berry et al. 2005). The current infrageneric classification of New World Croton based on molecular, morphological, and geographical data recognizes 31 sections (Van Ee et al. 2011). The new species belongs to Croton section Lamprocroton (Müll. Arg.) Pax, a South American group with high diversity in Brazil (Lima and Pirani 2008; Van Ee et al. 2011).

In Flora Brasiliensis (Müller 1873), the name "Lamprocroton" was used to designate one of the series of Croton sect. Decarinium (Raf.) Müll. Arg. Members of that series were characterized in Müller's work by the presence of lepidote trichomes. Later, Pax and Hoffman (1931) gave this taxon sectional status. Webster (1993), in his sectional synopsis of Croton, restricted the circumscription of Croton sect. Lamprocroton to species with lepidote trichomes, bifid styles (six stigmatic tips), and eglandular leaves. More recently, Lima and Pirani (2008) returned to Müller's (1873) broader circumscription of Croton sect. Lamprocroton, which also was supported by phylogenetic studies based on molecular data (Van Ee and Berry 2011; Van Ee et al. 2011). The section was divided into two subsections (Croton subsect. Lamprocroton (Müll. Arg.) B. W. van Ee \& P. E. Berry and Croton subsect. Argentini B. W. van Ee and P. E. Berry), which differ from each other by indumentum type and the number of stigmatic tips (Van Ee et al. 2011).

In its current circumscription, Croton section Lamprocroton comprises 37 species distributed in South America, and is represented by monoecious or dioecious shrubby species with lepidote or stellate trichomes, eglandular leaves, fewer than 16 stamens, and bifid or twice bifid styles (Lima and Pirani 2008; Van Ee and Berry 2011; Van Ee et al. 2011). According to Van Ee and Berry (2011), Croton sect. Lamprocroton subsect. Lamprocroton, with about 17 species, has primarily lepidote trichomes and styles with six stigmatic tips, whereas Croton sect. Lamprocroton subsect. Argentini, with about 20 species, has mainly stellate trichomes and styles with 12 or more stigmatic tips.
As part of taxonomic studies conducted in the state of Paraná in southern Brazil, we describe Croton longicarpus and place it in Croton sect. Lamprocroton subsect. Lamprocroton based on morphological data. We provide illustrations, a distribution map, and a key for the species of Croton subsect. Lamprocroton from southern Brazil.

\section{Materials AND Methods}

This study was based on field observations and the analysis of collections from the following herbaria: BHCB, ECT, FLOR, HFIE, HUCS, LUSC, MBM, MO, NY, RB, SP, and UPCB (Thiers 2017). Type collections and the protologues of related taxa also were studied for a better understanding of morphological affinities of the new species. Type specimens were analyzed through images available at the JSTOR Global Plants website (http://plants.jstor.org/). Morphological terms used in the description follow Radford et al. (1974), Webster et al. (1996), and Lima and Pirani (2008). Data about habit, habitat, and distribution were taken from specimen labels and field observations. The species distribution map was made using QGIS 2.10.1 (QGIS Development Team 2015). Geographic coordinates used for mapping were obtained from herbarium material or electronic gazetteers.

\section{TAXONOMIC TREATMENT}

Croton longicarpus A. P. N. Pereira, Caruzo \& Riina, sp. nov.TYPE: BRAZIL. PARANÁ: Rio Branco do Sul, rodovia PR092, sentido Cerro Azul, próximo ao km 40, orla de Floresta

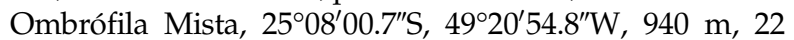
Nov 2016, A. P. N. Pereira, M. B. R. Caruzo \& R. Riina 46 (holotype: SP; isotypes: MBM, NY, RB).

Croton longicarpus is morphologically most similar to C. splendidus Mart. ex Colla. However, the two species differ in fruit and ovary morphology (narrowly ellipsoid in C. longicarpus vs. globose in C. splendidus), the sepals of their pistillate flowers (narrowly spatulate in C. longicarpus vs. ovate to obovate in C. splendidus), and seed color (gray with brown spots in C. longicarpus vs. brown without spots in C. splendidus).

Monoecious shrubs 1.5-3.0 m; branches cylindrical to flattened, slightly striated, covered by cream to golden, subentire lepidote trichomes; latex clear. Leaves entire, discolorous, without petiolar glands; lamina 3.0-7.0 $\times 0.6-1.4 \mathrm{~cm}$, narrowly lanceolate to lanceolate, apex acute to acuminate, sometimes mucronate, base acute to narrowly obtuse, margin entire, adaxial surface sparsely pubescent with stellate trichomes, abaxial surface densely aureo-lepidote; venation pinnate, 


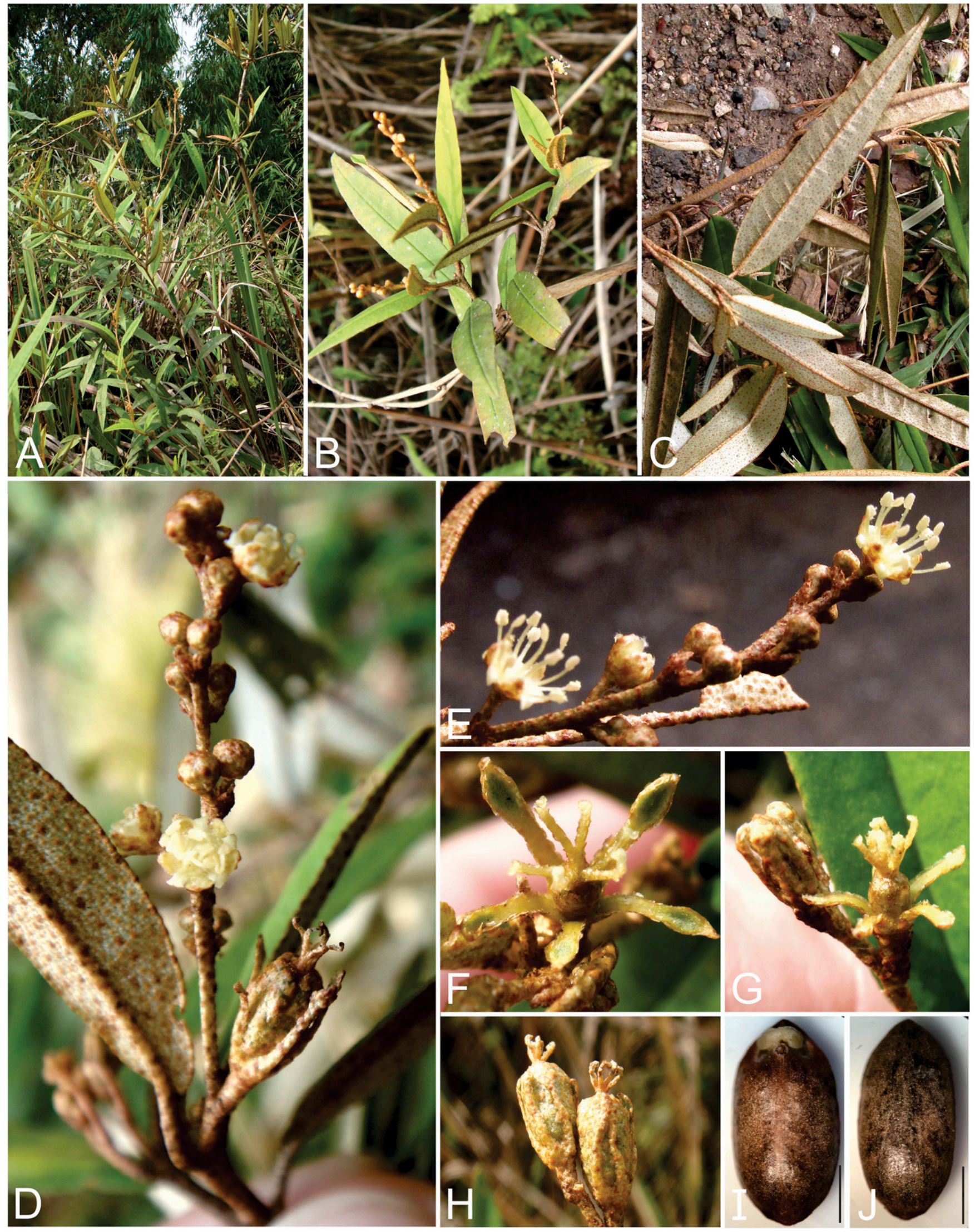

FIG. 1. Croton longicarpus. A. Habit. B. Detail of branches showing leaves and inflorescences. C. Leaves showing abaxial surface covered by aureo-lepidote indumentum. D. Detail of inflorescence showing young fruit and staminate flowers. E. Staminate flowers. F-G. Pistillate flowers showing narrowly spatulate sepals. H. Young fruits. I. Seed, ventral view, with tiny and reniform caruncle J. Seed in dorsal view. Scale bar $=1 \mathrm{~mm}$. Photos by the authors. 
camptodromous, primary veins impressed on the adaxial surface and raised on abaxial surface, secondary veins not raised on abaxial surface; stipules inconspicuous; petioles 2-9 mm long, covered by subentire lepidote trichomes. Inflorescences $1.5-11.0 \mathrm{~cm}$ long, terminal, bisexual, lower cymules unisexual, lax, axis flattened, covered by lepidote subentire trichomes; bracts ca. $3 \mathrm{~mm}$ long, triangular, adaxial surface glabrate, abaxial surface with subentire lepidote trichomes. Staminate flowers with pedicels ca. $2 \mathrm{~mm}$ long; sepals 5 , valvate, ca. $1.5 \times 1.0 \mathrm{~mm}$, ovate, apex acute, entire, equal, adaxial surface glabrate, abaxial surface with subentire lepidote trichomes; ca. $2.0 \times 0.5 \mathrm{~mm}$, petals narrowly elliptic, villous only along the margin; receptacle villous; stamens ca. 10; filaments glabrate; nectary disc 5-segmented. Pistillate flowers with pedicels ca. $1 \mathrm{~mm}$ long; sepals 5, valvate, 3.0-5.5 $\times 0.5-1.0 \mathrm{~mm}$, narrowly spatulate, apex slightly cucullate, entire, unequal, adaxial surface with subentire lepidote trichomes, abaxial surface with stellate trichomes; petals reduced to linear structures, ca. $0.5 \mathrm{~mm}$ long; ovary ca. $2.0 \times 0.5 \mathrm{~mm}$, ellipsoid, covered by stellate trichomes; styles bifid from near the base (with 6 terminal tips), covered by subentire lepidote trichomes; nectary disc entire, deeply 5-lobed. Fruits ca. $5.0 \times 2.0 \mathrm{~mm}$, narrowly ellipsoid. Seeds $4.0 \times 1.5 \mathrm{~mm}$, narrowly ellipsoid, smooth, gray with brown spots; caruncle tiny, ca. $0.5 \times 0.8 \mathrm{~mm}$, reniform, yellowish. Figures 1A-I, 2B, D.
Distribution and Habitat-Croton longicarpus has been collected in the Brazilian states of Paraná and Rio Grande do Sul (Fig. 3), in open vegetation ('campo sujo') and edges of Araucaria forest, between $860-1,000$ m elevation. It most likely also occurs in the state of Santa Catarina.

Phenology-Flowering September to March; fruiting from November to March.

Vernacular Name-"Velame" (A. Dunaiski Jr. \& W. do Amaral 2684).

Etymology-The specific epithet refers to the unusually elongated fruits, which are unique within Croton sect. Lamprocroton.

Notes About Conservation Status-Croton longicarpus can be considered Data Deficient (DD) because information about populations currently is insufficient to make a reliable conservation assessment (IUCN 2012).

Additional Specimens (Paratypes) Examined—BRAZIL. Paraná: Coronel Domingos Soares, São João, 22 Sep 2014, J. T. Motta \& J. M. Silva 4435 (MBM); Laranjeiras do Sul, Rio Reserva, 18 Mar 1967, J. Lindeman \& H. Haas 5019 (MBM, MO, NY); Mallet, Rio Bonito, 07 Nov 2005, R. Wasum, G. Heiden $\mathcal{E}$ D. Alessandretti 3167 (ECT, UHCS, MBM); Rio Branco do Sul, Caeté, 06 Nov 1977, G. Hatschbach 40358 (BHCB, MBM, MO); loc. cit., Serra do Bromado, 09 Feb 1982, G. Hatschbach 44543 (BHCB, MBM, MO); loc. cit, J. M. Silva, J. Cordeiro \& C. B. Poliquesi 6231 (MBM); loc. cit, Caverna da Caximba, 14 Nov 1996, G. Tiepolo \& A. C. Svolenski 643 (MBM, UPCB); loc. cit, Rodovia PR-092, 2507'33"S, 49²1'09"W, 1004 m, 11 Dec 2013, M. L. Brotto, J. T. Motta, J. M. Silva \& J. Vaz 1467 (MBM, RB); loc. cit, Vutuverava, 13 Mar 2005,
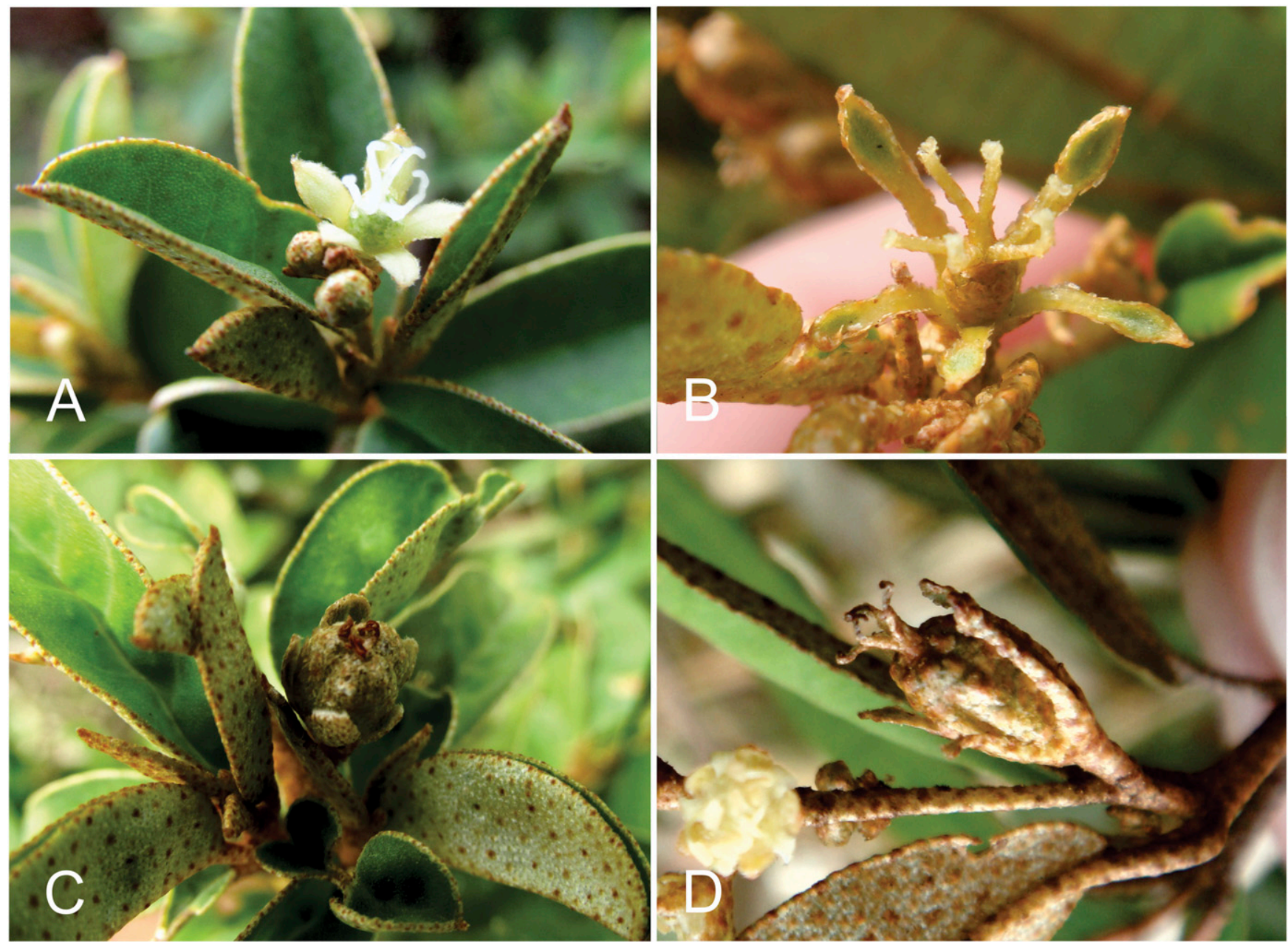

FIG. 2. Comparison of pistillate flower and fruit morphology between Croton longicarpus and C. splendidus. A. Pistillate flower of C. splendidus showing ovate to obovate sepals. B. Pistillate flower of C. longicarpus showing the narrowly spatulate sepals. C. Globose fruit of $C$. splendidus. D. Ellipsoid fruit of C. longicarpus. Photos by the authors. 


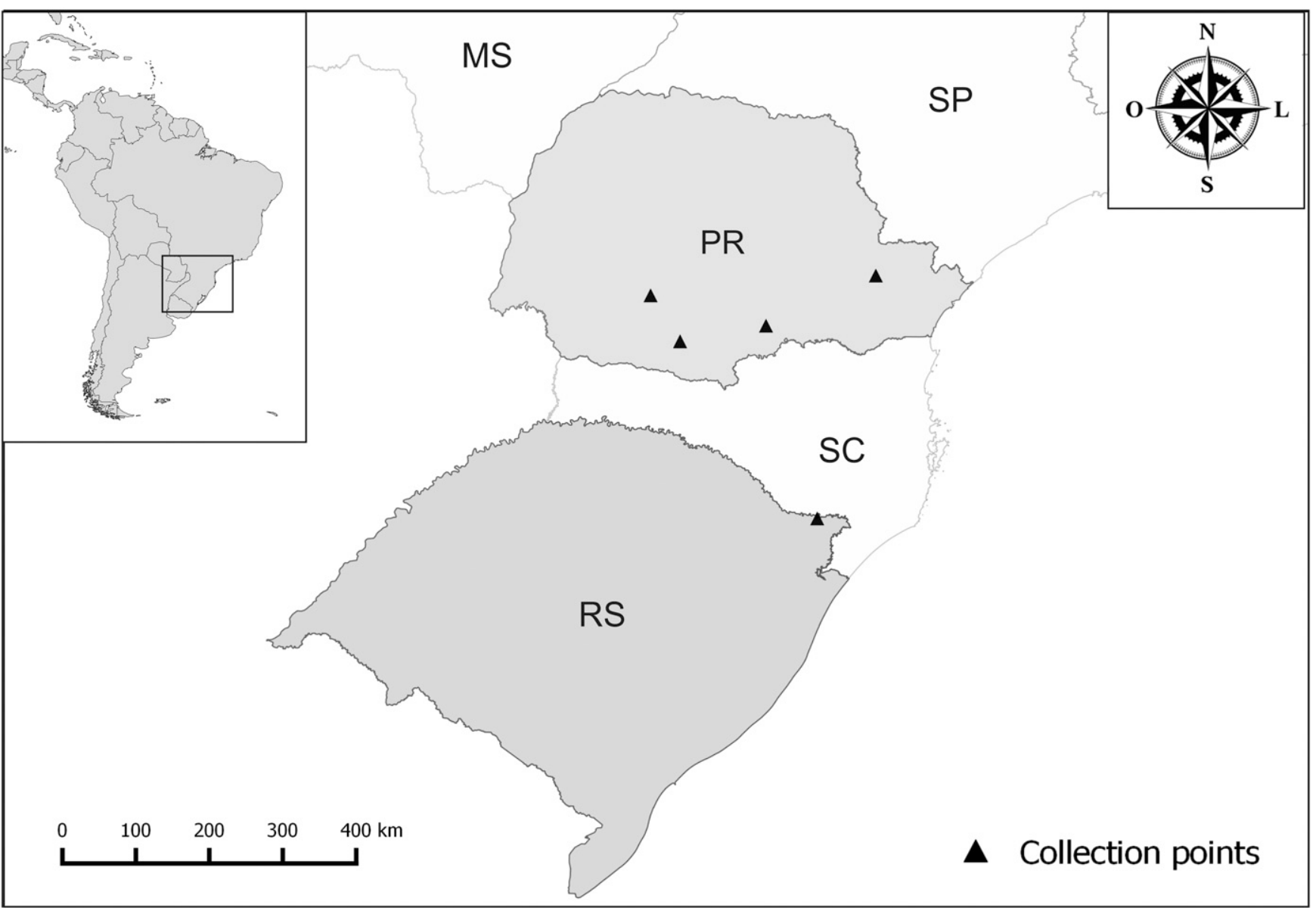

FIG. 3. Distribution map showing the current known localities of Croton longicarpus. States acronyms: MS $=$ Mato Grosso do Sul, PR $=$ Paraná, RS $=$ Rio Grande do Sul, SC = Santa Catarina, SP = São Paulo.

A. Dunaiski Jr. \& W. do Amaral 2684 (HFIE, MBM). Rio Grande do Sul: Bom Jesus, Fazenda Santo Inácio, 28 $22^{\circ} 53^{\prime \prime} \mathrm{S}, 50^{\circ} 08^{\prime} 48^{\prime \prime} \mathrm{W}, 865 \mathrm{~m}$, 13 Sep 2014 J. Cordeiro, E. Barboza, E. D. Lozano \& V. Ariati 5242 (FLOR, HUCS, LUSC, MBM).

\section{DISCUSSION}

Croton longicarpus is morphologically most similar to members of Croton sect. Lamprocroton due to the presence of lepidote trichomes, leaves without petiolar glands, and bifid styles (with six terminal tips). The new species is placed here in Croton sect. Lamprocroton subsect. Lamprocroton because of its lepidote indumentum and style branching with six terminal tips. Croton longicarpus differs from all the other species in Croton subsect. Lamprocroton by its unusually elongated ovary and fruit (Fig. 1D, H), narrowly spatulate sepals of the pistillate flowers (Fig. 1F), and long inflorescences (up to $11 \mathrm{~cm}$ long). The sepals of the pistillate flowers are also accrescent, and they are longer than the fruit (Fig. 1D).

Specimens of Croton longicarpus have been identified erroneously in herbaria as C. splendidus, a morphologically similar species in Croton sect. Lamprocroton subsect. Lamprocroton. However, these two species can be distinguished by the shape and size of their leaves (narrowly to broadly elliptic and ca. $2.5 \mathrm{~cm}$ long in C. splendidus vs. narrowly lanceolate to lanceolate and ca. $5 \mathrm{~cm}$ long in C. longicarpus), morphology of the pistillate sepals (ovate to obovate in C. splendidus [Fig. 2A] vs. narrowly spatulate in C. longicarpus [Fig. 2B]), presence or absence of lepidote trichomes on the styles (absent in

TABLE 1. Main characters distinguishing Croton longicarpus and other morphologically similar species.

\begin{tabular}{|c|c|c|c|}
\hline Morphological character & C. longicarpus & C. splendidus & C. uruguayensis \\
\hline Leaf shape & Narrowly lanceolate to lanceolate & Narrowly elliptic to broadly elliptic & $\begin{array}{l}\text { Narrowly elliptic, rarely } \\
\text { narrowly lanceolate }\end{array}$ \\
\hline Inflorescences & Bisexual & Bisexual & Unisexual \\
\hline Pistillate sepal shape & Narrowly spatulate & Ovate to obovate & Oblong \\
\hline Lepidote trichomes on styles & Present & Absent & Absent \\
\hline Ovary and fruit shape & Narrowly ellipsoid & Globose & Globose \\
\hline Seed color & Gray with brown spots & Brown & Brown \\
\hline
\end{tabular}


C. splendidus vs. present in C. longicarpus), and the morphology of ovary and fruit (globose in C. splendidus [Fig. 2C] vs. narrowly ellipsoid in C. longicarpus [Fig. 2D]).

Croton uruguayensis Baill., another species of Croton sect. Lamprocroton subsect. Lamprocroton found in southern Brazil, Argentina, Paraguay, and Uruguay, likewise is similar morphologically to $C$. longicarpus. The species can be confused due to their long inflorescences and narrow leaves; however, the inflorescences of C. uruguayensis are unisexual, the pistillate sepals are oblong, and its styles are glabrous, whereas in C. longicarpus the inflorescences are bisexual, the pistillate sepals are narrowly spatulate, and its styles are covered by lepidote trichomes (see also Table 1).
A few specimens of the new species were identified previously as Croton argyrophylloides Müll. Arg. (= C. tricolor Klotzsch ex Baill.), a shrubby species in Croton sect. Lasiogyne (Klotzsch) Baill. that occurs in seasonally dry forests of Brazil, Bolivia, Venezuela, and possibly Colombia (Gomes 2006; Caruzo and Cordeiro 2007; Berry and Riina 2008; Silva et al. 2010). These species are separated easily by morphological characters such as pistillate flower aestivation (reduplicatevalvate in C. tricolor vs. valvate in C. longicapus), style division (multifid in C. tricolor vs. bifid in C. longicarpus), ovary and fruit shape (subglobose in C. tricolor vs. ellipsoid in C. longicarpus), and seed coat ornamentation (rugose in C. tricolor vs. smooth in C. longicarpus).

\section{Key to the Species of CROton Sect. LAMProcroton SubSect. LAMProcroton From Southern BraziL (Paraná, Rio Grande do Sul, and Santa Catarina)}

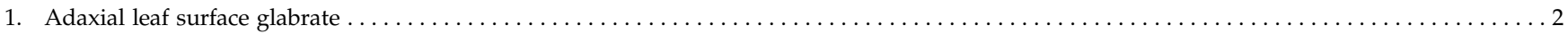

2. Leaves narrowly elliptic to narrowly lanceolate; inflorescences unisexual; plants from open vegetation or river bank ......... C. uruguayensis

2. Leaves broadly elliptic to widely ovate; inflorescences bisexual; plants from open vegetation in high altitude regions ('campo de altitude')

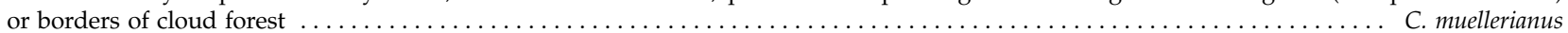

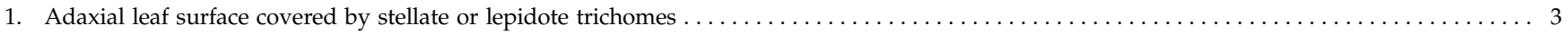

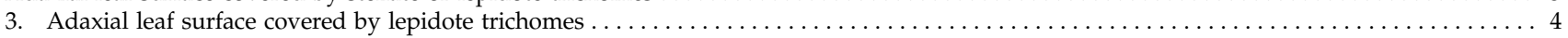

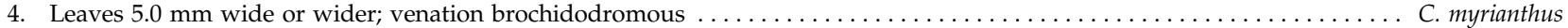

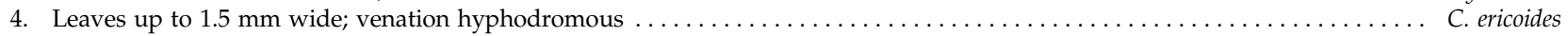

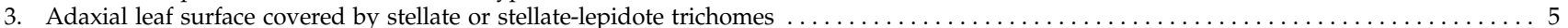

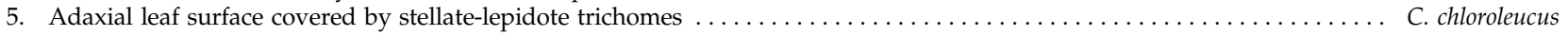

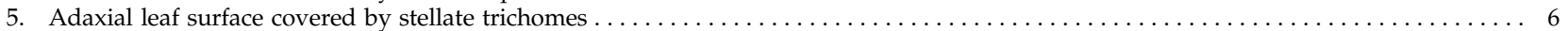

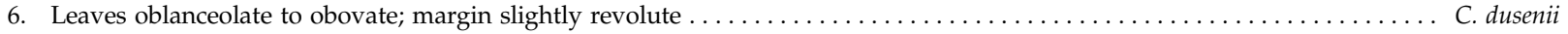

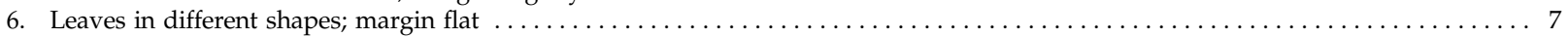

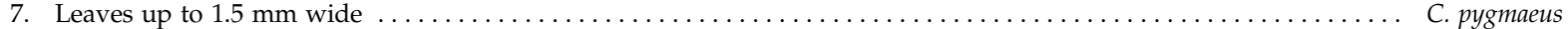

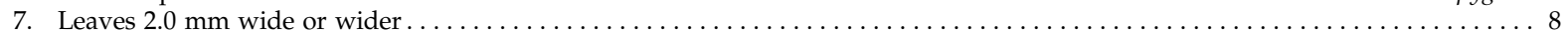

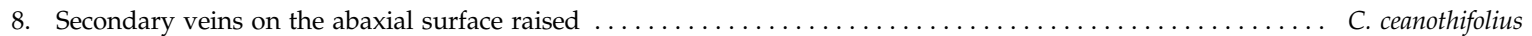

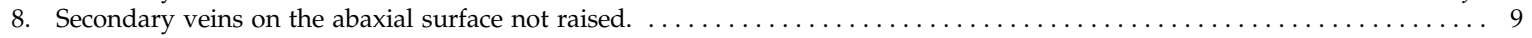
9. Leaves narrowly elliptic to broadly elliptic; fruit and ovary globose; seeds brown, without spots. .......... C. splendidus 9. Leaves narrowly lanceolate to lanceolate; fruit and ovary narrowly ellipsoid; seeds gray with brown spots ...... C. longicarpus

ACKNOWLEDGMENTS. The authors thank the curators and staff of BHCB, MBM, RB, SP, and UPCB for making their collections available. B. Van Ee and an anonymous reviewer provided useful suggestions. Financial support for the first author was provided by 'Coordenação de Aperfeiçoamento de Pessoal de Nível Superior' (Capes). This work is part of the master's thesis of A. P. N. Pereira.

\section{Literature Cited}

Berry, P. E., A. L. Hipp, K. J. Wurdack, B. W. Van Ee, and R. Riina. 2005. Molecular phylogenetics of the giant genus Croton and tribe Crotoneae (Euphorbiaceae sensu stricto) using ITS and trnL-trnF DNA sequence data. American Journal of Botany 92: 1520-1534.

Berry, P. E. and R. Riina. 2008. Croton - Euphorbiaceae. Pp. 366-380 in Nuevo Catálogo de la Flora Vascular de Venezuela (O. Hokche, P. E. Berry, and O. Huber, eds.). Caracas: Fundación Instituto Botánico de Venezuela, Caracas.

BFG - The Brazil Flora Group. 2015. Growing knowledge: an overview of seed plant diversity in Brazil. Rodriguésia 66: 1085-1113.

Caruzo, M. B. R. and I. Cordeiro. 2007. Sinopse da tribo Crotoneae Dumort. (Euphorbiaceae s. s.) no Estado de São Paulo, Brasil. Hoehnea 34: $571-585$

Gomes, A. P. S. 2006. Revisão das espécies sul-americanas de Croton sect. Argyroglossum Baill. (Crotonoideae, Euphorbiaceae). Ph.D. dissertation. Recife: Universidade Federal Rural de Pernambuco, Brasil.

Govaerts, R., D. G. Frodin, and A. Radcliffe-Smith. 2000. World checklist and bibliography of Euphorbiaceae (and Pandaceae), 4 vols. Royal Botanic Gardens, Kew.

IUCN. 2012. The IUCN red list categories and criteria. Version 3.1. Second edition. Gland, Switzerland and Cambridge, U. K.: IUCN.
Lima, L. R. and J. R. Pirani. 2008. Revisão taxonômica de Croton sect. Lamprocroton (Müll. Arg.) Pax (Euphorbiaceae s. s.). Biota Neotropica 8: 203-257.

Müller, J. 1873. Croton. Pp. $81-274$ in Flora brasiliensis 11 (2), ed. C. F. P. von Martius. München: Wien \& Leipzig.

Pax, F. and K. Hoffmann. 1931. Crotoneae. Pp. 83-88 in: Die natiirlichen Pflanzenfamilien, ed. 2, 19c, ed. A. Engler and K. Prantl. Leipzig: Wilhelm Engelmann.

QGIS Development Team. 2015. QGIS Geographic Information System. Open Source Geospatial Foundation. http://qgis.osgeo.org.

Radford, A. E., W. C. Dickson, R. Massey, and C. R. Bell. 1974. Vascular plant systematics. Harper \& Row Publishers, Inc., New York.

Silva, J. S., M. F. Sales, A. P. S. Gomes, and D. S. Carneiro-Torres. 2010. Sinopse das espécies de Croton L. (Euphorbiaceae) no estado de Pernambuco, Brasil. Acta Botanica Brasílica 24: 441-453.

Thiers, B. 2017 [continuously updated]. Index Herbariorum: A global directory of public herbaria and associated staff. New York Botanical Garden's Virtual Herbarium. http://sweetgum.nybg.org/ih/.

Van Ee, B. W. and P. E. Berry. 2011. Croton section Pedicellati (Euphorbiaceae), a novel New World group, and a new subsectional classification of Croton section Lamprocroton. Systematic Botany 36: 88-98.

Van Ee, B. W., R. Riina, and P. E. Berry. 2011. A revised infrageneric classification and molecular phylogeny of New World Croton (Euphorbiaceae). Taxon 60: 791-823.

Webster, G. L. 1993. A provisional synopsis of the sections of the genus Croton L. (Euphorbiaceae). Taxon 42: 793-823.

Webster, G. L. 1967. The genera of Euphorbiaceae in the Southeastern United States. Journal of the Arnold Arboretum 48: 363-430.

Webster, G. L., M. J. Del-Arco-Aguilar, and B. A. Smith. 1996. Systematic distribution of foliar trichome types in Croton (Euphorbiaceae). Botanical Journal of the Linnean Society 121: 41-57. 